\title{
Adaptation of an entrepreneurial motivation scale into Spanish
}

\author{
Joan Boada-Grau ${ }^{1 *}$, José Carlos Sánchez-García ${ }^{2}$, Eric Viardot ${ }^{3}$, María Boada-Cuerva ${ }^{4}$ and Andreu Vigil-Colet ${ }^{1}$
}

\author{
1 Universitat Rovira $i$ Virgili, Tarragona (España). \\ 2 Universidad de Salamanca (España). \\ 3 Escuela de Alta Dirección y Administración, Barcelona (España). \\ 4 Universitat Jaume I, Castellón (España).
}

\begin{abstract}
Título: Adaptación al español de una escala de motivación emprendedora. Resumen: Este estudio sigue el marco teórico propuesto por Robichaud sobre motivación emprendedora. El objetivo fue adaptar la escala original francesa de 17 ítems al español y analizar sus propiedades psicométricas. Los participantes del presente estudio fueron 981 empleados españoles (46.5\% hombres y $53.5 \%$ mujeres). Después de llevar a cabo el análisis factorial exploratorio y el ESEM (RMSEA $=.06$; CFI $=.95$ y TLI $=.95$ ), se determinó una estructura compuesta de tres factores: Seguridad de la familia $(\alpha=.82)$, Independencia y autonomía $(\alpha=.83)$ y Motivaciones intrínsecas $(\alpha=.77)$. Los tres factores muestran una fiabilidad adecuada. También se encuentran evidencias de validez respecto a una serie de correlatos externos y varias escalas que hacen alusión a la adicción al trabajo, la irritación y el burnout. La presente escala puede resultar adecuada para identificar adecuadamente la motivación emprendedora.
\end{abstract}

Palabras clave: motivación emprendedora; escalas; validez; empleo.

\section{Introduction}

The Global Entrepreneurship Monitor report (GEM, 2013) indicates that entrepreneurship is linked to the perception of opportunities, to orientation, to attitudes, to the fear of failure and to entrepreneurial motivations. In addition, the study suggests that the government authorities of the countries taking part in the study must not only focus on providing entrepreneurial people with external resources such as capital and easy financing terms but should also analyze their skills, their motivations and their experiences.

Many theoretical models have been developed to examine the entrepreneurial motivation construct (Robichaud, Cachon, \& Haq, 2010) because a closer understanding of motivations can contribute to a better understanding of entrepreneurial behaviour. As Morris, Miyasaki, Watters and Coombes (2006: 228) point out “....motivations for starting a venture would seem an important determinant of growth aspirations, as those who are motivated by the desire to get rich or to meet a challenge would seem more interested in growth than those motivated by discrimination or a desire for personal expression".

Carsrud and Brännback (2011) consider that entrepreneurial motivation is implicit in the tendency to become an entrepreneur, in cognitive adaptation (Sánchez-García, Boada-Grau, Prizmic-Kuzmica, \& Hernández-Sánchez, 2014) and entrepreneurial behaviors (De Jong, Parker, Wennekers, \& Wu, 2013; George \& Marino, 2011). Howev-

* Dirección para correspondencia [Correspondence address]

Dr. Joan Boada-Grau. Centre de Recerca d'Avaluació i Mesura de la Conducta (CRAMC). Departament de Psicologia. Universitat Rovira i Virgili. Carretera de Valls, s/n. 43007 Tarragona, Catalunya (España). E-mail: joan.boada@urv.cat; joan.boada.grau@gmail.com
Abstract: This study follows the theoretical framework put forward by Robichaud on entrepreneurial motivation. The objective was to adapt the original French scale of 17 items into Spanish and to analyze its psychometric properties. The participants in the present study were $981 \mathrm{Spanish}$ employees (46.5\% men and $53.5 \%$ women). After carrying out exploratory factor analyses and ESEM (RMSEA $=.06$; CFI $=.95$ and TLI $=.95)$, revealed a structure comprised of three factors: Family security $(\alpha=.82)$, Independence and autonomy ( $\alpha=.83$ ), and Intrinsic motivations $(\alpha=.77)$. These three factors displayed adequate reliability. We also found evidence of validity with regard to a series of external correlates and various scales that have to do with workaholism, irritation and burnout. The present scale may prove useful for adequately identifying entrepreneurial motivation.

Key words: entrepreneurial motivation; scales; validity; employment. er, there has been little research into interactions between these constructs (Carsrud \& Brännback, 2009).

The scientific literature has identified a wide range of entrepreneurial motivations ranging from the economic motivations to the non-economic. Various studies have pointed out gender differences in motivations whereby women tend towards a balance between the social and the economic sphere whereas men are more inclined to strive for monetary rewards (Cadieux, Lorrain, \& Hugron, 2002). In other studies, women were more likely to emphasize intrinsic motivations whilst men tended to place greater value on extrinsic motivations (Manolova, Brush, \& Edelman, 2008). Furthermore, the desire to start up their own venture among women entrepreneurs is motivated by the fact that it enables them to find a balance between work and their family life (Borges, Filion, \& Simard, 2008).

Naffziger, Hornsby and Kuratko (1994) argue that the decision to undertake a business venture is an outcome of various factors such as the individual's personal characteristics, their personal environment (influence of the family, spouse, etc.), their motivations, and the existence of a viable business idea. There are various motivations. Though the following does not by any means constitute a comprehensive list here are some of the key motivations: Independence (Williams, 2009), autonomy (Lumpkin, Cogliser, \& Schneider, 2009), financial goals (Pinfold, 2001), being one's own boss (Mattis, 2000), and seeking a challenge (Petrakis, 2007).

On the other hand, as Robichaud et al. (2010) point out, entrepreneurial motivations have also been depicted within the "push-pull" framework, whereby people who are "pushed" into self-employment find themselves in that position through necessity. Some employees are "pushed" towards entrepreneurship due to their frustration at working in a certain organisation, to job dissatisfaction, to the lack of 
promotion, to the non-existence of challenges and opportunities, to the need for more job flexibility, to the imbalance between work and leisure, and to the need to earn a better income (Minniti, Bygrave, \& Autio, 2006). Some studies have used the Robichaud et al. $(2001,2008,2010)$ scale to evaluate the entrepreneurial motivation, in particular those carried out by Barba-Sánchez and Atienza-Sahuquillo (2012) in Spain on a sample of entrepreneurs and by Cachon, Codina, EcciusWellmann, McGraw and Myers (2013) on a transcultural sample from the USA, Canada and Mexico. None of these studies adapted the Robichaud et al. (2001, 2008, 2010) scale because their objectives meant that this was unnecessary.

The present study analyses the adaptation of the Robichaud et al. (2001, 2008, 2010) entrepreneurial motivation scale into the Spanish language. The study's four objectives are: (1) to use Exploratory Factor Analysis (hereafter, EFA) to analyse the scale's internal structure, (2) to replicate the resulting structure with Exploratory Structural Equation Modelling (hereafter, ESEM), (3) to determine the scale's reliability or internal consistency, and (4) to look for evidence of convergent validity.

\section{Method}

\section{Participants}

The sample was made up of 981 employees from Spain. whose characteristics are described in Table 1.

\section{Instruments}

The Entrepreneurial Motivation scale (Robichaud \& McGraw, 2008; Robichaud, McGraw, \& Roger, 2001) evaluates the motivation for starting up a professional and business venture. In line with the guidelines outlined by various authors (Hambleton, Merenda, \& Spielberger, 2005; Muñiz, Elosua, \& Hambleton, 2013) we conducted the following: (1) we evaluated the importance of the construct because to date no Spanish scale for employee participants has been created; (2) for the linguistic adaptation we contacted native bilingual English-Spanish translators and expert professors in entrepreneurship with a command of both languages; (3) we independently carried out direct and back translations; (4) we conducted a pilot test on 50 employees which showed that the time needed was less than five minutes and which allowed us to correct some minor language issues; and (5) we used the list of twenty-five questions to control the quality of the translation-adaptation of the items proposed by Hambleton and Zenisky (2011). The French version consists of 17 items and 4 factors: 1 .-Independence and autonomy (5 items; $\alpha=.84$; for example, "being able to decide what I want to do"), 2.-Extrinsic motivations (4 items; $\alpha=.78$; for example, "To increase the profits and sales of my business"), 3.Family security (4 items; $\alpha=.75$; for example, "To be better prepared for my children") and 4.-Intrinsic motivations (4 items; $\alpha=.73$; for example, "To accomplish a challenge").
The response format was a Likert scale ranging from 1 to 5 $(1=$ not at all important to $5=$ very important $)$.

Table 1. Socio-demographic characteristics of the participants.

\begin{tabular}{|c|c|c|}
\hline & & $\begin{array}{c}\text { Participants } \\
(N=981)\end{array}$ \\
\hline Gender & $\begin{array}{c}\text { Men } \\
\text { Women }\end{array}$ & $\begin{array}{l}46.5 \% \\
53.5 \%\end{array}$ \\
\hline Age (years) & & $\begin{array}{c}M=45.32 \\
(S D=10.26)\end{array}$ \\
\hline Marital Status & $\begin{array}{c}\text { Married } \\
\text { De facto union } \\
\text { Single } \\
\text { Divorced / separated } \\
\text { Widowed }\end{array}$ & $\begin{array}{c}60.8 \% \\
6.9 \% \\
23.8 \% \\
7.5 \% \\
1.0 \%\end{array}$ \\
\hline Tenure (years) & $\begin{array}{l}\text { In their protessions } \\
\text { In their current company }\end{array}$ & $\begin{array}{c}M=9.4 \\
(S D=9.68) \\
M=14.20 \\
(S D=14.32) \\
M=11.34 \\
(S D=11.12)\end{array}$ \\
\hline
\end{tabular}

Educational

No academic certificate

$2.3 \%$ Completed primary education $\quad 21.7 \%$ Completed secondary education $\quad 38.2 \%$ A three-year university degree $\quad 19.3 \%$ A five-year university degree $\quad 13.5 \%$ Master / doctorate $\quad 5.0 \%$

Work contract types

Permanent (full-time)

Permanent (part-time)

Temporary (full-time)

Temporary (part time) Others

$57.7 \%$

$14.2 \%$

$9.9 \%$

$10.7 \%$

$7.5 \%$

Economic viewpoint the company's situation over the last 12 months

Employees work in the following sectors

\begin{tabular}{cc} 
Not at all stable & $8.4 \%$ \\
Somewhat stable & $21.4 \%$ \\
Quite stable & $39.2 \%$ \\
Very stable & $18.1 \%$ \\
Totally stable & $12.9 \%$ \\
& \\
Education & $26.25 \%$ \\
Construction & $25.56 \%$ \\
Transport & $16.38 \%$ \\
Healthcare & $12.42 \%$ \\
Industry & $11.41 \%$ \\
Retail & $3.49 \%$ \\
Hospitality & $2.10 \%$ \\
Others & $2.39 \%$ \\
\hline
\end{tabular}

The Spanish version of the Workaholism scale (WorkBAT; McMillan, Brady, O'Driscoll, \& Marsh, 2002) drawn up by Boada-Grau, Prizmic-Kuzmica, Serrano-Fernández and Vigil-Colet (2013) has 19 items and 2 subscales. The first subscale is " $D$ (Driven)" and is made up of 12 items $(\alpha=.82$; for example, "I would often like not to be so committed to my work"), the second subscale "J (Work Enjoyment)" con- 
sists of 7 items $(\alpha=.83$; for example, "My work is so interesting that it often doesn't seem like work"). The response format was a Likert one to five scale (From 1=Totally disagree to $5=$ Totally agree).

The Spanish version of the Irritation scale (Irritation Scale; Mohr, Müller, Rigotti, Aycan \&Tschan, 2006) drawn up by Merino Carbonero, Moreno, \& Morante, (2006) consists of 8 items and 2 subscales. The first subscale is "Emotional irritation" $(\alpha=.86)$ and is made up of 5 items (for example, "When other people talk to me I respond rudely"). The second subscale is "Cognitive irritation" $(\alpha=.87)$, and is made up of 3 items" (for example, "I find it hard to switch off after work"). Responses were registered on a 7-point Likert scale (from 1.-Very much disagree to 7.-Very much agree).

The Spanish version of the Maslach Burnout InventoryGeneral Survey (MBI-GS; Salanova, Schaufeli, Llorens, Peiró, \& Grau, 2000) is comprised of 15 items and 3 subscales. Responses were registered on a 6-point scale (ranging from "never" to "every day"). The subscales were: professional efficacy $(\alpha=.78$ ) comprised of 6 items (for example, "I have accomplished many worthwhile things in this job"); cynicism $(\alpha=.85$ ), which is comprised of 4 items (for example, "I have lost enthusiasm for my job") and exhaustion $(\alpha=.87)$ made up of 5 items (for example, "I am 'burnt out' by the job").

Finally, a series of external correlates were also used in order to evaluate convergent validity (Boada-Grau et al., 2013). These were in the form of questions which the informants were asked to answer using frequencies.

\section{Procedure}

We began by requesting permission from the managers of the companies and organisations. Second, we contacted the employees to recruit them for the survey. Third, we administered the scales during working hours and on an individual basis, ensuring that the data was kept strictly confidential and anonymous.

\section{Data analysis}

The total sample of 981 employees was randomly divided into two subsamples of 491 and 490 employees respectively. The first sample (491 employees) was used to perform an EFA using Promin extraction methods (Lorenzo-Seva, 1999). This was done using the FACTOR 7.2 programme (Lorenzo-Seva \& Ferrando, 2006) because on the one hand, it enables you to carry out the analysis using polychoric correlation matrices, which are more suitable when the items' response format is a Likert type scale (Muthen \& Kaplan, 1992) and, on the other hand, it allows you to decide the number of factors you wish to retain following the parallel analysis (Timmerman \& Lorenzo-Seva, 2011). The programme SPSS 20.0 was used to analyse the properties of the items, the internal consistency of the scales and the validity coefficients.

The second subsample (490 employees) was used to perform a confirmatory factor analysis (hereafter, CFA) based on the factor structure found in the EFA. This was done by ESEM (Asparouhov \& Muthén, 2009) using Mplus software (6.12 Version).

ESEM is an alternative to the traditional CFA proposed by Marsh, Liem, Martin, Morin and Nagengast (2011) and is designed to overcome the adjustment problems that occur when applying CFA to typical performance measures. This approach enables you to merge the best aspects of CFA, EFA and structural equation models into a comprehensive framework whilst adding flexibility to all of the subcomponents (Marsh, Lüdtke, Nagengast, Morin, \& Von Davier, 2013).

In short, ESEM (Morin, Marsh, \& Nagengast, 2013) uses a measurement model based on an EFA and its corresponding rotation, to which a structural equations model is applied, thus combining the flexibility of EFA with the usual adjustment indices provided by structural equation models (Mai \& Wen, 2013). This enables analyses to be carried out that confirm the factor structure proposed in a previous EFA, as in the present case, or even more complex analyses such as factor invariance studies (Chahin, Cosí, Lorenzo-Seva, \& VigilColet, 2010).

\section{Results}

An EFA was performed on sample $1(\mathrm{~N}=491)$ using the FACTOR 7.2 programme (Lorenzo-Seva, 1999). The KaiserMeyer-Olkin sample appropriateness rate (KMO) was .825 , which shows that it is ideal for its factorization. We also obtained the results of Bartlett's test of sphericity (Chi-square= 3262.3; $d f=78$; $p<.01$ ). Two criteria were also added in order to confirm the number of factors to be considered, parallel analysis (Lattin, Carroll, \& Green, 2003) and Vellicer's "minimum average partial" criterion (1976). These criteria pointed to the suitability of the three factor solution.

After obtaining the most suitable factor solution, we simplified this by using the Promin rotation method (Lorenzo-Seva, 1999). This method tends to obtain the simplest factor solution possible (Table 2). 
Table 2. EM Scale: Factor saturations matrix extracted from the exploratory factor analysis.

\begin{tabular}{|c|c|c|c|c|}
\hline \multirow[t]{2}{*}{ Items } & \multirow[t]{2}{*}{ (a) } & \multicolumn{3}{|c|}{ (b) } \\
\hline & & F1 & $\mathrm{F} 2$ & F3 \\
\hline $\begin{array}{l}\text { 1.-Poder para decidir lo que yo quiero hacer [1.-Pouvoir décider de que je veux faire] [1.- } \\
\text { Power to decide what I want to do] }\end{array}$ & $\begin{array}{l}\text { 1.-Independence and auton- } \\
\text { omy }\end{array}$ & .09 & .41 & .16 \\
\hline 2.-Crear mi propio trabajo [3.-Créer mon propre emploi] [3.-Setting up my own job] & $\begin{array}{l}\text { 1.-Independence and auton- } \\
\text { omy }\end{array}$ & -.10 & .94 & .00 \\
\hline 3.-Ser mi propio jefe [4.-Etre mon propre patron] [4.-Being my own boss ] & $\begin{array}{l}\text { 1.-Independence and auton- } \\
\text { omy }\end{array}$ & .00 & .89 & -.04 \\
\hline $\begin{array}{l}\text { 4.-Obtener una seguridad personal que me garantiza un trabajo propio [5.-Obtenir une sécuri- } \\
\text { té personnelle en me garantissant un emploi] [5.-Achieving personal security that guarantees } \\
\text { a job of my own ] }\end{array}$ & $\begin{array}{l}\text { 1.-Independence and auton- } \\
\text { omy }\end{array}$ & .26 & .40 & .11 \\
\hline $\begin{array}{l}\text { 5.-Maximizar el crecimiento de mi negocio [9.- Maximiser la croissance de mon entreprise] } \\
\text { [9.-Optimising the growth of my enterprise] }\end{array}$ & 2.-Extrinsic motivations & .52 & .25 & .06 \\
\hline $\begin{array}{l}\text { 6.-Construir de algo que podría beneficiar a mis hijos [10.- Bâtir quelque chose pouvant bé- } \\
\text { néficier à mes enfants] [10.-Building something that could benefit my children] }\end{array}$ & 3.-Family security & .83 & .13 & -.10 \\
\hline $\begin{array}{l}\text { 7.-Estar más preparado para mis hijos [11.- Etre plus prêt de mes enfants] [11.-Being better } \\
\text { prepared for my children] }\end{array}$ & 3.-Family security & .81 & -.08 & .04 \\
\hline $\begin{array}{l}\text { 8.-Protejer la situación financiera de mi familia [12.- Sécuriser la situation financière de ma } \\
\text { famille] [12.-Protecting my family's financial position] }\end{array}$ & 3.-Family security & .79 & -.02 & .05 \\
\hline $\begin{array}{l}\text { 9.-Construir un fondo de pensiones para la vejez [13.-Bâtir un fond de pension pour mes } \\
\text { vieux jours] [13.-Building a pension fund for my old age] }\end{array}$ & 3.-Family security & .63 & .10 & .08 \\
\hline 10.-Conseguir un reto [14.- Relever un défi] [14.-Accomplishing a challenge] & 4.-Intrinsic motivations & -.11 & .00 & .87 \\
\hline $\begin{array}{l}\text { 11.-Ayudar a mi desarrollo personal [15.-Aider à mon développement personnel] [15.- } \\
\text { Furthering my personal development] }\end{array}$ & 4.-Intrinsic motivations & -.10 & .02 & .94 \\
\hline $\begin{array}{l}\text { 12.-Darme a conocer en la comunidad [16.-Me faire connaittre dans la communauté] [16.- } \\
\text { Making myself known in the community] }\end{array}$ & 4.-Intrinsic motivations & .21 & .00 & .42 \\
\hline $\begin{array}{l}\text { 13.-Demostrar que puedo tener éxito en lo que emprendo [17.-Prouver que je peux réussir ce } \\
\text { que j'entreprends] [17.-Demonstrating that I can achieve success in my undertakings] }\end{array}$ & 4.-Intrinsic motivations & .24 & .04 & .46 \\
\hline $\begin{array}{l}\text { Mantener una sensación de libertad e independencia [2.-Maintenir un sentiment de liberté } \\
\text { et d'indépendance] [2.-Maintaining a sense of freedom and independence ] }\end{array}$ & $\begin{array}{l}\text { 1.-Independence and auton- } \\
\text { omy }\end{array}$ & (c) & & \\
\hline $\begin{array}{l}\text { Aumentar los beneficios y las ventas de mi negocio [6.-Augmenter les profits et les ventes } \\
\text { de mon entreprise] [6.-Increasing my business's profits and sales] }\end{array}$ & 2.-Extrinsic motivations & (c) & & \\
\hline $\begin{array}{l}\text { Crear una empresa que me permita vivir cómodamente [7.- Bâtir une entreprise qui me } \\
\text { permet de vivre confortablement] [7.-Setting up an enterprise that will enable me to live } \\
\text { comfortably] }\end{array}$ & 2.-Extrinsic motivations & (c) & & \\
\hline $\begin{array}{l}\text { Aumentar la cantidad de dinero que recibo de mi empresa [8.-Augmenter les sommes } \\
\text { d'argent que je tire de mon entreprise] [8.-Increasing the amount of money I get from my } \\
\text { enterprise] }\end{array}$ & 2.-Ext & (c) & & \\
\hline Explained variation $(\%)$ & & 47.2 & 10.5 & 10.1 \\
\hline
\end{tabular}

(a) Robichaud \& McGraw's original scale (2008).

(b) Version in Spanish (F1.-Family security, F2.-Independence and autonomy, F3.-Intrinsic motivations)

(c) Item deleted in the Spanish version.

An ESEM was performed on sample $2(\mathrm{~N}=490)$ in order to confirm the EFA structure. The indices were: the root mean square error of approximation (RMSEA $\leq .06)$, the comparative fit index $(C F I \geq .95)$ and the Tucker-Lewis index (TLI $\geq .95)$. The results displayed a good fit for the three factor model given that the values of the indices (RMSE $A=.06 ; C F I=.95$ and $T L I=.95)$ were within the appropriate range. The one, two and four factor models were ruled out because they did not fit.
Table 3 was drawn up using the total sample. It displays the average, the standard deviation, the reliability, the reliability intervals and the correlations of the three factors on the scale that we presented, along with three contrast scales and seventeen external correlates in order to confirm validity. It also displays reliability for the three subscales. As far as evidence of validity is concerned, the table shows the significant correlations between the three factors and other variables. 
Table 3. Factors of the EM scale: descriptive statistics, reliability, confidence intervals and correlations with external variables and factors from the (WorkBAT, Irritation and MBI-GS) scales, as well as matrix of correlations among the three factors of the scale under analysis.

\begin{tabular}{|c|c|c|c|c|}
\hline & & F1 & $\mathrm{F} 2$ & F3 \\
\hline $\bar{M}$ & & 16.54 & 20.36 & 15.38 \\
\hline$S D$ & & 3.36 & 4.09 & 3.21 \\
\hline Reliability & & .82 & .83 & .77 \\
\hline Confidence Interval & & $.80-.84$ & $.81-84$ & $.75-.80$ \\
\hline \multirow[t]{17}{*}{ External Correlates } & Age & $.10^{* *}$ & $.11 * *$ & $-.10^{* *}$ \\
\hline & Annuity in current job & .05 & $.06^{*}$ & $-.08 *$ \\
\hline & Annuity in this profession & .03 & .04 & $-.09 * *$ \\
\hline & Annuity in current company & .03 & .03 & $-.09 * *$ \\
\hline & Feeling healthy & .05 & .05 & $.08^{*}$ \\
\hline & Feeling happy in your life & $.07 *$ & $.07 *$ & .06 \\
\hline & Number of overtime hours per year & $-.12 *$ & -.09 & -.01 \\
\hline & Having power and social prestige & $.17^{* *}$ & $.19 * *$ & $.28^{* *}$ \\
\hline & Achieving personal success & $.18^{* *}$ & $.18^{* *}$ & $.35^{* *}$ \\
\hline & Getting pleasure and ludic gratification & $.15^{* *}$ & $.16^{* *}$ & $.27 * *$ \\
\hline & Having new developments and changes in life & $.18^{* *}$ & $.19 * *$ & $.33^{* *}$ \\
\hline & Having greater independence & $.21 * *$ & $.21 * *$ & $.23^{* *}$ \\
\hline & Getting away from a routine job & $.11 * *$ & $.11 * *$ & $.14^{* *}$ \\
\hline & Feeling of personal fulfillment & $.23^{* *}$ & $.23 * *$ & $.42^{* *}$ \\
\hline & Having more freedom on the job & $.19 * *$ & $.20 * *$ & $.25^{* *}$ \\
\hline & Having job security & $.36 * *$ & $.38^{* *}$ & $.20 * *$ \\
\hline & Having an idea to set up your own company & .05 & .05 & $.19 * *$ \\
\hline \multirow[t]{2}{*}{ WorkBAT } & D-Driven & $.22 * *$ & $.20 * *$ & $.26 * *$ \\
\hline & J-Work Enjoyment & $.13^{* *}$ & $.19 * *$ & $.18^{* *}$ \\
\hline \multirow[t]{2}{*}{ Irritation } & Emotional & $.15^{* *}$ & $.12^{* *}$ & $.10^{*}$ \\
\hline & Cognitive & $.11 *$ & .08 & $.10^{*}$ \\
\hline \multirow[t]{3}{*}{ MBI-GS } & Burnout & .03 & .01 & -.01 \\
\hline & Cynicism & $-.11 *$ & $-.14^{* *}$ & $-.11 *$ \\
\hline & Personal efficacy & $.13^{* *}$ & $.14^{* *}$ & $.16^{* *}$ \\
\hline $\mathrm{F} 1$ & & -- & -- & -- \\
\hline $\mathrm{F} 2$ & & .43 & -- & -- \\
\hline $\mathrm{F} 3$ & & .54 & .42 & -- \\
\hline
\end{tabular}

** $p<.01 ; * p<.05$

F1.-Family security.

F2.-Independence and autonomy.

F3.-Intrinsic motivations

\section{Discussion}

In the present study we have presented the psychometric properties of the Spanish version of the entrepreneurial motivation scale (Robichaud \& McGraw, 2008; Robichaud et al., 2001) consisting of 13 items. This instrument enables us to evaluate the motivation for undertaking a professional or business venture. Furthermore, this is the first time this scale has been adapted into Spanish.

The first objective was not corroborated. The results of the EFA on a heterogeneous Spanish sample did not support the four-factor model of the French version proposed and designed by (Robichaud \& McGraw, 2008; Robichaud et al., 2001), nor of its predecessor drawn up by Kuratko, Hornsby and Naffziger (1997).

The first factor of the Spanish version, "Family security", is related to motivations such as increasing the growth of the business, being able to provide for one's children, being qualified, ensuring financial protection for the family and putting money aside for old age. It accounts for $47.2 \%$ of variance and comprises five items, 5, 6, 7, 8 and 9. The fac- tor is identical in content to the one proposed by Robichaud and collaborators (Robichaud \& McGraw, 2008; Robichaud et al., 2001), which has four items. However, the Spanish version included an extra item which was taken from the extrinsic motivations factor (item 9 in the French version, "Maximizing the growth of my business"). This first factor is also similar in content to the one proposed by Kuratko et al. (1997) which also focuses on family security.

The second factor in the Spanish version, "Independence and autonomy", comprises four items (1, 2, 3 and 4) which accounted for $10.5 \%$ of variance. It refers to aspects such as employees deciding on what they want to do, creating their own job, creating something of their own and seeking personal security. This factor is the same as the French version (Robichaud \& McGraw, 2008; Robichaud et al., 2001), except for the fact that the latter has one more item (5 items). One item, "maintaining a sense of freedom and independence", was removed in the Spanish version because its factor weight was under .30. As with the original French version, this factor also has 5 items in Kuratko et al. (1997). 
The last factor, "Intrinsic Motivations", is related to overcoming a challenge, furthering personal development, making oneself known in one's environment and demonstrating the ability to successfully start up a project. It accounts for $10.1 \%$ of variance and comprises four items, 10 , 11, 12 and 13. This factor is identical to that of the French version (Robichaud \& McGraw, 2008; Robichaud et al., 2001) which has four items and is equivalent to that of $\mathrm{Ku}-$ ratko et al. (1997), which comprises 5 items.

In the Spanish version of the scale the three factors account for a total variance of $67.8 \%$. In the scale by Kuratko et al. (1997) they account for $60.3 \%$ and in that of Robichaud and collaborators (Robichaud \& McGraw, 2008; Robichaud et al., 2001) 59.6\%. After correlating the three factors in our scale, we found moderate associations: .42 (F2 and F3), .43 (F1 and F2) and .54 (F1 and F3), which indicates that these are different dimensions.

The second objective was because the ESEM was found to support the three-factor model obtained by the EFA. All of this was corroborated by the ensuing indices which showed a good fit for the model (RMSEA $=.06$; CFI $=.95$ and TLI $=.95)$. It should be pointed out that no other author has carried out this type of analysis on the published scales.

Reliability, understood as internal consistency, is a measure of the homogeneity of the items in a test (DeVellis, 2003). Hence the third objective was achieved given that we found adequate reliability for the three subscales in the Spanish version, which fluctuated between .77 and .83 . Reliability for the French version varied between .73 and .84. In contrast, the reliability of the Kuratko et al. scale (1997) was lower and fluctuated between .66 and .80 .

The fourth objective was fulfilled because the three subscales correlated to the contrast scales and various external criteria and thus showed evidence of validity. Significant correlations were found, both positive and negative. In general, the three factors correlated positively with the correlates we used, for example "achieving personal success", "having new developments and life changes", "having more freedom at work", etc.). It should also be mentioned that all three correlate positively with workaholism, emotional irritation and personal efficacy. However, some subscales presented negative correlations with age, annuity, the amount of overtime and cynicism. It should be pointed out that the versions drawn up by Kuratko et al. (1997) and Robichaud and collaborators (Robichaud \& McGraw, 2008; Robichaud et al., 2001) do not provide data on evidence of validity.

\section{References}

Asparouhov, T., \& Muthén, B. (2009). Exploratory structural equation modeling. Structural Equation Modeling, 16, 397-438.

Boada-Grau, J., Prizmic-Kuzmica, A. J., Serrano-Fernández, M. J., \& VigilColet, A. (2013). Factorial structure, reliability and validity of the workaholism scale (WorkBAT): Spanish version. Anales de Psicologia, 29, 923933.
To conclude, on the basis of our study's findings, we can state that the Spanish version of the entrepreneurial motivation scale presents acceptable psychometric properties and may prove useful for evaluating motivations that drive entrepreneurship. It comprises 13 items and 3 factors and displays appropriate reliability and evidence of validity. It is therefore a streamlined instrument that is easy to understand and quick to apply-interpret.

We consider that the present study contributes to the body of knowledge regarding various aspects of entrepreneurial motivation. The results have important practical implications and pave the way for future research. The present scale could prove useful to governments concerned about implementing policies and programmes that help create employment. They could use this instrument to evaluate the types of motivation underlying all entrepreneurial processes. The present study was carried out with employees and workers and therefore also needs to be replicated with university students, entrepreneurs and business owners. In addition to this, research also needs to be conducted to determine whether university education stimulates the motivation to start up a venture. Finally, research also needs to be conducted to look for variables such as creativity, proactivity, risk taking and family culture, among others, in the backgrounds of individuals who show an interest in entrepreneurial motivation.

The present study has various certain limitations. First, we would need to analyse the discriminant validity of the scale (Padilla, Gómez, Hidalgo, \& Muñiz, 2007) among different groups such as students, workers, entrepreneurs and business owners. Second, the use of self-reporting may have led to a greater association among the variables due to the variance from the common method (Podsakoff, MacKenzie, Lee, \& Podsakoff, 2003), although it should be pointed out that self-reporting has been widely used in research studies on entrepreneurial motivation (Kuratko et al., 1997; Robichaud et al., 2001; Williams, 2009). Thirdly, we used incidental sampling whereas future research should use probability sampling. Convenience samples are very frequently used when drawing up scales in the field of psychological science (Muñiz, Elosua, \& Hambleton, 2013) and in research on entrepreneurial motivation (Morales-Gualdrón, GutiérrezGracia, \& Roig-Dobón, 2009; Robichaud \& McGraw, 2008). Hence, the use of convenience samples does not pose an important threat to the study's validity (Highhouse and Gillespie, 2008). This type of sampling is often chosen due to practical, economic and logistic limitations.

Barba-Sánchez, V., \& Atienza-Sahuquillo, C. (2012). Entrepreneurial behavior: Impact of motivation factors on decision to create a new venture. European Research Management and Business Economics, 18, 132-138.

Borges, C., Filion, L. J., \& Simard, G. (2008). Specificities of the Venture Creation Process by Women. Paper presented at the Annual Conference of the ICSB/CIPE. Halifax, N.S., June. 
Cachon, J.C., Codina, J.B., Eccius-Wellmann, C., McGraw, E., \& Myers, DA (2013). Entrepreneurial motives and performance: Evidence from North America. Journal of Management Policy and Practice, 14, 50-77.

Cadieux, L., Lorrain, J., \& Hugron, P. (2002). La succession dans les entreprises familiales dirigées par les femmes: une problématique en quête de chercheurs. Revue Internationale P.M.E, 15, 115-130.

Carsrud, A., \& Brännback, M. (2011). Entrepreneurial motivations: What do we still need to know? Journal of Small Business Management, 49, 9-26.

Carsrud, A., \& Brännback, M. (Eds.) (2009). Understanding the Entrepreneurial Mind: Opening the Black Box. Heidelberg: Springer.

Chahin, N., Cosí, S., Lorenzo-Seva, U., \& Vigil-Colet, A. (2010). Stability of the factor structure of Barrat's Impulsivity Scales for children across cultures: A comparison of Spain and Colombia. Psicothema, 22, 983-989.

De Jong, J.P.J.,Parker, S.K.,Wennekers, S.,\& Wu, C.H.(2013). Entrepreneurial behavior in organizations: Does job design matter?. Entrepreneurship Theory and Practice, December, 1-15.

DeVellis, R.F. (1991). Scale development: Theory and applications, Newbury Park : Sage Publications.

GEM (2013). Global Entrepreneurship Monitor 2013 Global Report. Chile, Santiago: Global Entrepreneurship Research Center at School of Business and Economics, Universidad del Desarrollo.

George, B.A., \& Marino, L. (2011). The epistemology of entrepreneurial orientation: Conceptual formation, modeling, and operationalization. Entrepreneurship Theory and Practice, September, 989-1023.

Hambleton, R.K., Merenda, P.F., \& Spielberger, C.D. (2005). Adapting educational and psychological tests for cross-cultural assessment. London: Erlbaum.

Hambleton, R.K., \& Zenisky, A.L. (2011). Translating and adapting tests for cross-cultural assessments. In D. Matsumoto y F.J.R. van de Vijver (Eds.), Cross-cultural research methods in psychology (pp. 46-70). Nueva York: Cambridge University Press.

Highhouse, S., \& Gillespie, J. Z. (2008). Do samples really matter that much? En C.E. Lance y R. J. Vandenberg (Eds.), Statistical and methodological myths and urban legends: Received doctrine, verity, and fable in the organizational and social sciences (pp. 247-266). Mahwah, NJ: Erlbaum

Kuratko, D. F., Hornsby, J. S., \& Naffziger, D. W. (1997). An examination of owner's goals in sustaining entrepreneurship. Journal of Small Business Management, 35, 24-33.

Lattin, J., Carroll, D. J., \& Green, P. E. (2003). Analyæing multivariate data. Pacific Grove. Duxbury Press.

Lorenzo-Seva, U. (1999). Promin: a method for oblique factor rotation. Multivariate Behavioral Research, 34, 347-365.

Lorenzo-Seva, U., \& Ferrando, P.J. (2006). FACTOR: A computer program to fit the exploratory factor analysis model. Behavioral Research Methods, Instruments and Computers, 38, 88-91.

Lumpkin, G.T., Cogliser, C.C., \& Schneider, D.R. (2009). Understanding and measuring autonomy: An entrepreneurial orientation perspective. Entrepreneurship Theory and Practice, January, 47-69.

Mai, Y., \& Wen, Z. (2013). Exploratory Structural Equation Modeling (ESEM): An Integration of EFA and CFA. Advances in Psychological Science, 21, 934-939.

Manolova, T.S., Brush, G.B., \& Edelman, L.F. (2008). What do woman entrepreneurs want?. Strategic Change 17, 69-82.

Marsh, H. W., Liem, G. A. D., Martin, A. J., Morin, A. J. S., \& Nagengast, B. (2011). Methodological measurement fruitfulness of exploratory structural equation modeling (ESEM): New approaches to key substantive issues in motivation and engagement. Journal of Psychoeducational Assessment, 29, 322-346.

Marsh, H.W.,Lüdtke, O.,Nagengast, B.,Morin, A.J. S., \& Von Davier, M. (2013). Why item parcels are (almost) never appropriate: Two wrongs do not make a right-Camouflaging misspecification with item parcels in CFA Models. Psychological Methods, 18, 257-284.

Mattis, M.C. (2000). Women entrepreneurs in the United Sates. In M.J. Davidson \& R.J. Burke, Women in management: current research issues (pp. 5368). Thousand Oaks, CA: Sage.

McMillan, L.H.W., Brady, E.C., O'Driscoll, M.P., \& Marsh, N. V. (2002). A multifaceted validation study of Spence and Robbins' (1992). Workaholism Battery. Journal of Occupational and Organizational Psychology, 75, 357-368.
Merino, E., Carbonero, M. A., Moreno, B., \& Morante, M.E. (2006). Irritation: Analysis of an instrument to assess stress at work. Psicothema, 18, 419-424

Minniti, M., Bygrave, W., \& Autio, E. (2006). Global entrepreneurship monitor: 2005 Executive Report. London: London Business School.

Mohr, G., Müller, A., Rigotti, T., Aycan, Z., \& Tschan, F. (2006). The assessment of psychological strain in work contexts: concerning the structural equivalency of nine language adaptations of the Irritationscale. European Journal of Psychological Assessment, 22, 198-206.

Morales-Gualdrón, S.T., Gutiérrez-Gracia, A., \& Roig-Dobón, S. (2009). The entrepreneurial motivation in academia: a multidimensional construct. International Entrepreneurship and Management Journal, 5, 301-317.

Morin, A.J.S., Marsh, H.W., \& Nagengast, B. (2013). Exploratory Structural Equation Modeling (Chapter 10). In Hancock, G. R., \& Mueller, R. O. (Eds.). (2013). Structural equation modeling: A second course. Charlotte, NC: Information Age Publishing, Inc.

Morris, M.H., Miyasaki, N.N., Watters, C.E., \& Coombes, S.M. (2006). The dilemma of growth: Understanding venture size choices of women entrepreneurs. Journal of Small Business Management, 44, 221-244.

Muñiz, J., Elosua, P., \& Hambleton, R. K. (2013). International Test Commission Guidelines for test translation and adaptation: Second edition. Psicothema, 25, 151-157.

Muthen, B., \& Kaplan, D. (1992). A comparison of some methodologies for the factor analysis of non-normal Likert variables: A note on the size of the model. British Journal of Mathematical and Statistical Psychology, 45, 19-30.

Naffziger, D.W., Hornsby J.S., \& D.F. Kuratko (1994). A proposed research model of entrepreneurial motivation. Entrepreneurial Theory and Practice, Printemps, 29-41.

Padilla, J. L., Gómez. J., Hidalgo. M. D., \& Muñiz. J. (2007). Esquema conceptual y procedimientos para analizar la validez de las consecuencias del uso de los test [Conceptual framework and procedures to assess the validity of the consequences of the use of tests]. Psicothema, 19, 173178

Petrakis, P. E. (2007). The effects of risk and time on entrepreneurship. International Entrepreneurship and Management Journal, 3, 277-291.

Pinfold, J.F. (2001). The expectations of new business founders: The New Zealand case. Journal of Small Business Management, 39, 279-285.

Podsakoff, P. M., MacKenzie, S. B., Lee, J. Y., \& Podsakoff, N. P. (2003). Common method biases in behavioral research: a critical review of the literature and recommended remedies. Journal of Applied Psychology, 88, 879-903.

Robichaud, Y., \& McGraw, E. (2008). Les motivations entrepreneuriales comme facteur explicative de la taille des entreprises. Journal of Small Business and Entrepreneurship, 21, 1, 59-74.

Robichaud, Y., Cachon, J. C., \& Haq, R. (2010). Motives, success factors, and barriers among Canadian female entrepreneurs: The case of Greater Sudbury. Entrepreneurial Practice Review, 1, 36-65.

Robichaud, Y., McGraw, E., \& Roger, A. (2001). Toward the development of a measuring instrument for entrepreneurial motivation. Journal of Developmental Entrepreneurship, 6, 189-201.

Salanova, M., Schaufeli, W.B., Llorens, S., Peiró, J.M. \& Grau, R. (2000). Desde el 'burnout' al 'engagement': cuna nueva perspectiva? [From burnout to 'engagement': a new perspective?]. Revista de Psicología del Trabajo y las Organizaciones, 16, 117-134.

Sánchez-García, J.C., Boada-Grau, J., Prizmic-Kuzmica, A-J., \& Hernández-Sánchez, B. (2014). Psychometric properties and the factor structure of the Spanish version of the cognitive adaptability (MAC) scale. Universitas Psychologica, 13, 1-18.

Timmerman, M.E., \& Lorenzo-Seva, U. (2011). Dimensionality assessment of ordered polytomous items with parallel analysis. Psychological Methods, 16, 209-220.

Vellicer, W. F. (1976). Determining the number of components from the matrix of partial correlations. Psychometrika, 41, 321-327.

Williams, C.C. (2009). The motives of off-the-books entrepreneurs: necessity- or opportunity-driven? International Entrepreneurship and Management Journal, 5, 203-217.

(Article received: 14-01-2015; revised: 13-05-2015; accepted: 22-06-2015) 